\section{Kentucky Bluegrass Response to Use of Aquatic Plants as a Soil Amendment}

\author{
A. Fortuna ${ }^{1}$ \\ U.S. Department of Agriculture, Agricultural Research Service, New EnglandPlant, \\ Soil, and Water Laboratory, University of Maine, Orono, ME 04469-5753
}

P.E. Rieke and L.W. Jacobs

Department of Crop and Soil Sciences, Michigan State University, East Lansing, MI 48824-1325

\section{B. Leinauer \\ Extension Plant Science Department, New Mexico State University, Las Cruces, NM 88003}

D.E. Karcher

Department of Horticulture, University of Arkansas, Fayetteville, AR 72701

Additional index words. organic residuals, nitrogen, carbon, mineralization, kinetics, trace metals, turfgrass quality, Poa pratensis

\begin{abstract}
Rapid aquatic plant growth in Michigan's smaller lakes has reduced their navigability and recreational use. Harvested aquatic weeds have posed a new waste disposal issue for municipalities. Application of lake weeds as a soil amendment on area farms was viewed as a possible waste management option that might benefit local sod producers. The objectives of this study were to 1 ) estimate the amount of plant-available $N$ (PAN) released from lake weed material, 2) determine the chemical composition of aquatic plant tissues and their effect on plant-available moisture, and 3) study turfgrass response to lake weed applications using the criteria of turfgrass quality, growth, and $\mathrm{N}$ uptake. Rates of lake

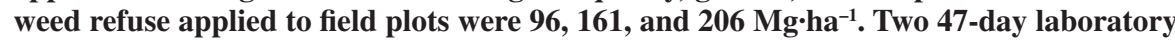
incubations were conducted with the same rates of refuse. Relative to biosolids, the metal content of the lake weeds was low and the nutrient content high. One megagram of lake weeds contained $0.37 \mathrm{~kg}$ of $P$ and $2.5 \mathrm{~kg}$ of $\mathrm{K}$. The decay constant for the $\mathrm{C}$ fraction in lake weeds was 8 to 10 days and 16 days for the $\mathbf{N}$ fraction. Estimates of the $\mathbf{N}$ supplied by lake weeds $(570,960$, and $1200 \mathrm{~kg}$ PAN/ha) were based on data from $\mathrm{C}$ and $\mathrm{N}$ incubations. Application of lake weeds significantly increased plant-available soil moisture and significantly enhanced sod establishment and turf density, resulting in decreased weed pressure. However, excess $\mathrm{N}$ was present at higher application rates. Management concerns during the application of lake weeds should focus on nutrient loading and the timing of plant-available $\mathbf{N}$ release. Depending on methods of weed harvesting, we observed that large amounts of unwanted trash present in the plant biomass could discourage use by growers. Land application of lake weed refuse could ease waste disposal problems, reduce fertilizer inputs for sod growers, and improve the moisture status of sands. Further, this information can be of value to environmental regulatory agencies in determining safe and proper use of such waste materials.
\end{abstract}

Various organic materials including biosolids, yard waste, and paper sludge have been used effectively as soil amendments to turfgrass (Hartz et al., 1996; Loschinkohl and Boehm, 2001; Norrie and Gosselin, 1996). In one instance, composted biosolid wastes improved turfgrass establishment and reduced leaf rust severity (Loschinkohl and Boehm, 2001).

Received for publication 2 Dec. 2003. Accepted for publication 18 May 2004. Mention of trade names or commercial products in this article is solely for the purpose of providing specific information and does not imply recommendation or endorsement by the U.S. Department of Agriculture. The authors would like to thank Marvin DeBuck for allowing us to conduct research on his sod farm. Support for this project was provided by Michigan State University Agricultural Experiment Station and The Michigan Turfgrass Foundation.

${ }^{1}$ To whom reprint requests should be addressed; e-mail ann-marie.fortuna@maine.edu.
However, soil amendments such as paper sludge contain low levels of macronutrients and require the addition of supplemental fertilizer to be used as an effective soil amendment (Norrie and Gosselin, 1996). Manure often contains excess $\mathrm{N}$ and $\mathrm{P}$ (Dou et al., 2001). To prevent nutrient loading or deficiencies, wastes should be analyzed for nutrient content, $\mathrm{C}$ to $\mathrm{N}$ ratio, organic matter content, trace elements, and soluble salts before use as an organic amendment (Hartz et al., 1996; Landschoot and McNitt, 1994).

Aquatic weed production in Lake St. Clair was unusually high in the mid-1990s. While this production is often dependent on excess nutrients, particularly $\mathrm{P}$, an additional complicating factor occurred due to improved water clarity caused by the filtering capacity of zebra mussels (Dreissena polymorpha) that had proliferated in the great lakes region. With better water clarity, the amount of radiant energy captured by aquatic plants increased, resulting in higher respiration rates and biomass production (Griffiths, 1993; Nalepa et al., 1996). This rapid aquatic plant growth has reduced the navigability and recreational use of smaller lakes at times, requiring that tons of aquatic weeds be harvested to reduce this problem. Stockpiled decaying plant material on park beaches has further impeded public use of these lakes. Since plant residues are commonly left after harvest and incorporated into agricultural soils, we hypothesized that application of lake weeds as a soil amendment to area farms was a waste management option that might also benefit local producers.

A waste application study was launched in conjunction with a local sod farm in the Summer 1995. Elemental analysis of the lake weed tissue was necessary to determine the quantity of plant nutrients and trace elements in this plant biomass. Organic wastes that contained excess nutrients or toxic components would be an environmental hazard and potentially decrease sod productivity. In order to determine the amount of inorganic $\mathrm{N}$ available to turfgrass sod, an estimate of the $\mathrm{N}$ mineralized from organic $\mathrm{N}$ in lake weeds was essential. Carbon decomposition data has been used to estimate net $\mathrm{N}$ mineralization of applied materials in the first $30 \mathrm{~d}$ after application (Gilmour et al., 1985). The objectives of this study were to 1) estimate the amount of plant-available $\mathrm{N}$ (PAN) released from lake weed material, 2) determine the chemical composition of aquatic plant tissues and their effect on plant-available moisture, and 3) study turfgrass response to lake weed applications using the criteria of turfgrass quality, growth, and $\mathrm{N}$ uptake.

\section{Materials and Methods}

Field site. A field study was established on the DeBuck Sod Farm, Macomb, Mich., during August 1995. Our research site was located on a Selfridge series (loamy, mixed, mesic, Aeric Ochraqualfs) with a cation exchange capacity of $7.5 \mathrm{cmol} \cdot \mathrm{kg}^{-1}$ and organic matter (C) content of $7 \mathrm{~g} \cdot \mathrm{kg}^{-1}$ soil. The area contained sand ridges left by receding waters after glacial retreat. Sod in this portion of the farm was irrigated to prevent wilting. Application of large quantities of organic matter in the form of lake weed was expected to decrease susceptibility to drought. Lime at $2240 \mathrm{~kg} \cdot \mathrm{ha}^{-1}$ was applied to raise the $\mathrm{pH}$ of the research plots from 5.9 to 6.5 . Soil test results indicated that K was low 146 $\mathrm{kg} \cdot \mathrm{ha}^{-1}$. Before application of lake weeds, 560 $\mathrm{kg} \cdot \mathrm{ha}^{-1}$ of $6 \mathrm{~N}-12 \mathrm{P}_{2} \mathrm{O}_{5}-36 \mathrm{~K}_{2} \mathrm{O}$ fertilizer was applied to the research plots and disked. Plot size was $6 \times 4.5-\mathrm{m}$. The statistical design of the research site was a randomized complete block with four replications. Main plot treatments included three rates of lake weeds and an untreated control.

Large applications of lake weed refuse were intended to increase the water holding capacity of the amended soil which would subsequently accelerate turfgrass establishment. In August, freshly harvested lake weed materials were adjusted to compensate for variations in moisture content resulting in application rates 
of 96,161 , or $206 \mathrm{Mg} \cdot \mathrm{ha}^{-1}$ on a dry weight basis. Plots were disked to incorporate lake weed refuse into the soil. On 16 Sept. 1995, a blend of kentucky bluegrass, Poa pratensis L. (30\% 'Victa', 30\% 'Abbey', 20\% 'Bristol', and $20 \%$ 'Coventry') was seeded on the plot area. Because of poor growth, the sod grower requested additional $\mathrm{N}$ be applied to the control and lake weed plots receiving the lowest rate. One application of urea was applied on 20 June 1996 to the control plots of $\mathrm{N}$ at $45 \mathrm{~kg} \cdot \mathrm{ha}^{-1}$ and $22 \mathrm{~kg} \cdot \mathrm{ha}^{-1}$ on the $96 \mathrm{Mg} \cdot \mathrm{ha}^{-1}$ treatment. The 161 and $206 \mathrm{Mg} \cdot \mathrm{ha}^{-1}$ lake weed treatments received no supplemental $\mathrm{N}$.

Chemical composition of St. Clair aquatic lake weeds. The composition of the harvested aquatic plant species collected on 22 July 1995 in St. Clair, Mich., from eight separate piles of lake weeds was determined to be wild celery (Vallisneria americana Michx.), eurasian watermilfoil (Myriophyllum spicatum L.), duckweed (Lemna minor), coontail (Ceratophyllum demersum L.), and waterweed (Elodea canadensis Michx.). Each lake weed species was found in each of the eight piles. Subsamples of mixed-species plant tissue were taken randomly throughout each of the 8 piles and composited. Subsamples weighed about 2 $\mathrm{kg}$ each. Elemental analyses for $\mathrm{P}, \mathrm{K}, \mathrm{Ca}, \mathrm{Mg}$, $\mathrm{Zn}, \mathrm{B}, \mathrm{Mn}, \mathrm{Fe}, \mathrm{Cu}, \mathrm{Al}, \mathrm{Na}$, and Mo were run in duplicate on the eight subsamples of mixedspecies plant tissue. Samples were oven dried at $60{ }^{\circ} \mathrm{C}$ and ground to pass a $0.55-\mathrm{mm}$ sieve. Plant tissue was ashed in a muffle furnace at 500 ${ }^{\circ} \mathrm{C}$ for $5 \mathrm{~h}$ and the ash dissolved using $3 \mathrm{~N}$ nitric acid. Ash solutions also contained $1000 \mathrm{mg} \cdot \mathrm{L}^{-1}$ $\mathrm{LiCl}$ for emission background correction and were analyzed on a direct current plasma atomic emission spectrometer (Spectrospan VB; Beckman Inst. Inc., Fullerton, Calif.). Total $\mathrm{N}$ in plant tissue was determined using the total Kjeldahl N method (TKN) (Bremner and Mulvaney, 1982). Total C in plant tissue was measured by combustion on a $\mathrm{C}$ Analyzer (Leco Corp., St. Joseph, Mich.).

Laboratory incubation study. Cumulative $\mathrm{N}$ data provided an estimate of the $\mathrm{N}$ fertilizer equivalence of lake weed refuse. A $47 \mathrm{~d} \mathrm{C}$ and $\mathrm{N}$ incubation study was conducted with soil $(0$ to $25 \mathrm{~cm})$ and lake weed materials from the DeBuck Sod Farm. Total C in soil was measured by dry combustion on a carbon analyzer (Leco Corp., St. Joseph, Mich.). Composite samples (2-cm-diameter cores, 12 to $15 \mathrm{sub}$ samples) were collected from each plot to a 25-cm depth in August 1995 before application of lake weeds. Samples were placed into a cooler, sieved through a 4-mm screen, and stored at $4{ }^{\circ} \mathrm{C}$ before $\mathrm{N}$ analysis. Samples to be used for $\mathrm{C}$ incubations were sieved through a 4-mm screen and air dried. For incubations, fifty grams of soil were added to a quart mason jar and dried lake weeds were applied and mixed into the soil at rates equivalent to those used in the field $(96,161$, and $206 \mathrm{Mg}$ lake weeds/ha) plus untreated soil. All treatments were run in duplicate and incubated at $25^{\circ} \mathrm{C}$. Distilled water was added to bring the soil or soil/lake weed mixture to $40 \%$ of water holding capacity (WHC) determined via the funnel method (Paul et al., 2001). Lids were fitted with rubber stoppers and sealed with vacuum grease containing no silica. A set of treatments was used to measure $\mathrm{CO}_{2}$ production at day $0,2,4,7,10,14,30,38$, and 47. Gas samples were analyzed for $\mathrm{CO}_{2}$ concentrations on an infrared gas analyzer (Analytical Development Co. Ltd., Hoddesdon, U.K.). A separate set of incubation treatments were run for $\mathrm{N}$ in duplicate at day $7,14,38$, and 47 . The samples were extracted using $1 \mathrm{~N} \mathrm{KCl}$ solution for available $\left(\mathrm{NH}_{4}+\mathrm{NO}_{3}\right)-\mathrm{N}$. The extracts were run on an auto analyzer (Lachat Instruments, Milwaukee, Wis.).

Curve fitting and statistics. A first order exponential single pool model (Talpaz et al., 1981) was used for curve fitting of cumulative $\mathrm{N}$ and $\mathrm{C}$ data:

$\mathrm{N}=\mathrm{N}_{\mathrm{o}}[1-\exp (-\mathrm{kt})]$ and $\mathrm{C}=\mathrm{C}_{\mathrm{o}}[1-\exp (-\mathrm{kt})]$ [Eq. 1]

Parameters $\mathrm{N}_{\mathrm{o}}$ and $\mathrm{C}_{\mathrm{o}}$ are the potentially mineralizable soil $\mathrm{N}$ and $\mathrm{C}$ pools at time zero often defined as the asymptote. Time $=(\mathrm{t})$ in days or weeks and $\mathrm{k}=$ the decay constant. Fitting the $\mathrm{C}$ and $\mathrm{N}$ curves provides an estimate of $\mathrm{k}$ and $\mathrm{N}_{0}$ or $\mathrm{C}_{0}$. The parameter $\mathrm{N}_{0}$ is an estimate of the amount of $\left(\mathrm{NH}_{4}+\mathrm{NO}_{3}\right)-\stackrel{\circ}{\mathrm{N}}$ supplied by the lake weed refuse for turfgrass uptake.

Soil controls containing no lake weeds were subtracted from the lake weed and soil treatments before curve fitting analysis. Curves were fit on the basis of $\mathrm{N}$ released from lake weeds per total $\mathrm{N}$ applied in lake weed refuse. Curves were fit on the basis of $\mathrm{C}$ released from lake weeds per total $\mathrm{C}$ applied in lake weed refuse. The single pool exponential model was fitted using nonlinear least squares (NLLS) regression and parameters were estimated with Marquardt's method in the Statistical Analysis System (SAS Institute Inc., 1988). A sum of squares reduction test was used to determine if the reduced model that assumes there are differences between lake weed rates was significantly different from the full model that assumes there are no differences. Where the reduced model was significantly different, a sum of squares reduction test was applied to treatment differences, using $\mathrm{F}$ values with $P=0.05$.

Soil physical properties. Capillary porosity and total porosity were determined on undisturbed soil samples. Soil samples were taken in metal cores $(7.5 \mathrm{~cm}$ in diameter and $7.5 \mathrm{~cm}$ in height) from below the thatch layer at the end of the study. Capillary porosity was determined based on water retention at $-4 \mathrm{kPa}$ tension. Water retention values were obtained by exposing the saturated samples for $48 \mathrm{~h}$ to a pressure of $-4 \mathrm{kPa}$ in pressure chambers (American Society for Testing and Materials, 1997). Dry soil bulk density was calculated by dividing the weight of oven dried soil $\left(105^{\circ} \mathrm{C}, 24 \mathrm{~h}\right)$ by the volume of the soil core (Danielson and Sutherland, 1986). Total porosity was derived from dry soil bulk density and particle density of the soil (American Society for Testing and Materials, 1997). Particle density was determined by the pycnometer method. Volumetric pycnometers were filled with air-dried samples of the soil, distilled water was added and the entrapped air was removed by subjecting the sample to a partial vacuum with a bell jar. The results were then corrected for water content of the air-dried samples (American Society for Testing and Materials, 1997; Blake and Hartge, 1986). Data were subsequently analyzed for treatment effects using ANOVA with alpha $=0.05$. Fisher's protected least significant difference procedure was used to determine significant differences between treatment means.

Assessment of turfgrass sod establishment, growth, and quality. The percentage of turfgrass cover was visually assessed on 20 June 1996 and was based on the amount of soil vs. sod. Turfgrass quality was rated on a 1 to 9 scale ( $9=$ ideal, $6=$ acceptable, and $1=$ no grass $)$ in each plot on 20 June, 3 July, 21 Sept., and 16 Nov. 1996. Assessment of turfgrass quality was based on turfgrass color, density, and uniformity. Turfgrass growth was estimated within a $6 \times 4.5 \mathrm{~m}$ long treatment area by collecting clippings from one pass with a bagging rotary mower set at a height of $5 \mathrm{~cm}$ on 3 July, 19 July, 6 Aug., 21 Sept., and 26 Oct. 1996. Clippings were weighed, dried at $60^{\circ} \mathrm{C}$, reweighed and analyzed for $\mathrm{N}$ content using near infrared analysis (NIR) (Turf Anser model 591 Scanner; Karsten Turf, Phoenix, Ariz.). Estimation of tissue $\mathrm{N}$ content in turfgrasses using NIR correlate well with TKN methods (Rodriguez and Miller, 2000). The presence of broadleaf and crabgrass weeds was evaluated on 20 June and 2 Sept. in 1996, respectively, by visually rating plots using a 1 to 9 scale $(1=$ absence of weeds, 9 = entirely weeds). Percent turf cover, quality, growth, $\mathrm{N}$ tissue content, and weed presence data were analyzed for treatment effects using ANOVA with alpha $=0.05$. When treatment effects were significant, means were separated according to Fisher's protected least significant difference procedure.

\section{Results and Discussion}

Lake weed nutrient content. Chemical analysis revealed that the lake weeds were a valuable source of nutrients and did not contain high quantities of trace elements (Table 1). Trace elements are elements that occur in very small quantities in organisms but nonetheless are needed for many biological processes. The $\mathrm{CV} \%$ values for the chemical composition of lake weeds indicate that the material is fairly uniform with the exception of $\mathrm{Cu}$. The mean $\mathrm{N}$ content of lake weeds was $29.0 \mathrm{~g} \cdot \mathrm{kg}^{-1}$. The mean $\mathrm{P}$ and $\mathrm{K}$ contents of the lake weeds were $3.0 \mathrm{~g} \cdot \mathrm{kg}^{-1} \mathrm{P}$ and $34 \mathrm{~g} \cdot \mathrm{kg}^{-1} \mathrm{~K}$. Fertilizer equivalents for the nutrients in the lake weeds based on total $\mathrm{P}$ and $\mathrm{K}$ were $0.85 \mathrm{~kg} \cdot \mathrm{Mg}^{-1} \mathrm{P}_{2} \mathrm{O}_{5}$ and $3.5 \mathrm{~kg} \cdot \mathrm{Mg}^{-1} \mathrm{~K}_{2} \mathrm{O}$. The $\mathrm{C}$ to $\mathrm{N}$ ratio of the lake weeds used for the incubations ranged from 9 to 11 with a mean of 10 similar to that of the soil $(\mathrm{C}: \mathrm{N}=11)$. The amount of $1 \mathrm{~N} \mathrm{KCl}$ extractable $\left(\mathrm{NH}_{4}+\mathrm{NO}_{3}\right)-\mathrm{N}$ on day 47 of laboratory incubations was used to calculate an $\mathrm{N}$ fertilizer equivalency of 570,960 , and $1200 \mathrm{~kg}$ PAN/ha. Compared to organic residuals such as leaf litter $\left(\mathrm{N}\right.$ at $9.4 \mathrm{~g} \cdot \mathrm{kg}^{-1}, \mathrm{P}$ at $1.0 \mathrm{~g} \cdot \mathrm{kg}^{-1}, \mathrm{~K}$ at $3.6 \mathrm{~g} \cdot \mathrm{kg}^{-1}, \mathrm{Mn}$ at 19 to $1845 \mathrm{mg} \cdot \mathrm{kg}^{-1}$, and $\mathrm{Zn}$ 22 to $\left.392 \mathrm{mg} \cdot \mathrm{kg}^{-1}\right)($ Heckman and Kluchinski, 1996), the lake weeds contained significant amounts of nutrients and a minimum amount 
Table 1. Elemental composition of lake weed.

\begin{tabular}{lccccc}
\hline & \multicolumn{5}{c}{ Elemental composition $\left(\mathrm{g} \cdot \mathrm{kg}^{-1}\right)$} \\
\cline { 2 - 5 } Component & Min & Max & Median & Mean & $\mathrm{CV}^{2}(\%)$ \\
\hline $\mathrm{C}$ & 258 & 347 & 304 & 309 & 11 \\
$\mathrm{~N}$ & 26.8 & 32.9 & 29.0 & 29.0 & 6.0 \\
$\mathrm{P}$ & 2.30 & 3.00 & 3.00 & 3.00 & 8 \\
$\mathrm{~K}$ & 27.2 & 41.2 & 35.0 & 34.0 & 14 \\
$\mathrm{Ca}$ & 15.8 & 43.3 & 23.0 & 25.0 & 32 \\
$\mathrm{Mg}$ & 3.10 & 4.60 & 4.00 & 4.00 & 11 \\
$\mathrm{Zn}$ & 0.079 & 0.150 & 0.091 & 0.098 & 23 \\
$\mathrm{~B}$ & 0.138 & 0.460 & 0.308 & 0.302 & 37 \\
$\mathrm{Mn}$ & 0.442 & 0.751 & 0.640 & 0.638 & 15 \\
$\mathrm{Fe}$ & 1.33 & 3.78 & 1.79 & 1.97 & 39 \\
$\mathrm{Cu}$ & 0.016 & 0.284 & 0.023 & 0.055 & 169 \\
$\mathrm{Al}$ & 0.925 & 3.48 & 1.59 & 1.69 & 46 \\
$\mathrm{Na}$ & 6.29 & 10.8 & 9.02 & 8.99 & 15 \\
$\mathrm{Mo}$ & 0.015 & 0.028 & 0.022 & 0.022 & 23 \\
\hline
\end{tabular}

${ }^{\mathrm{z}} \mathrm{CV}$, standard deviation expressed as a percentage of the mean of 16 samples.

Table 2. Readily available $\mathrm{C}$ and $\mathrm{N}$ pools, mean decomposition rates (k), mean residence times (MRT), and percent decomposition of substrate $\mathrm{C}$ and $\mathrm{N}$.

\begin{tabular}{|c|c|c|c|c|c|}
\hline $\begin{array}{l}\text { Readily } \\
\text { available pool of } \\
\text { Lake weed } C^{z}\end{array}$ & $\begin{array}{c}\mathrm{k} \\
\left(\mathrm{d}^{-1}\right)\end{array}$ & $\begin{array}{l}\text { MRT } \\
\text { (d) }\end{array}$ & $\begin{array}{c}\text { Pool } \\
\text { size } \\
\left(\mathrm{g} \cdot \mathrm{kg}^{-1}\right)^{\mathrm{y}}\end{array}$ & $\begin{array}{c}\text { C evolved from } \\
\text { lake weed C }(\%) \\
\text { Day } 47\end{array}$ & $\begin{array}{c}\mathrm{N} \text { evolved from } \\
\text { lake weed } \mathrm{N}(\%) \\
\text { Day } 47\end{array}$ \\
\hline \multicolumn{6}{|c|}{ Lake weed application rate $\left(\mathrm{Mg} \cdot \mathrm{ha}^{-1}\right)$} \\
\hline 96 & 0.130 & 8 & 540 & 55 & 20 \\
\hline 161 & 0.126 & 8 & 599 & 60 & 23 \\
\hline 206 & 0.096 & 10 & 647 & 62 & 17 \\
\hline Lake weed $\mathrm{N}^{\mathrm{x}}$ & 0.064 & 16 & 225 & & \\
\hline
\end{tabular}

${ }^{2}$ The pool size is the $\mathrm{g}$ of $\mathrm{C}$ or $\mathrm{N}$ available per $\mathrm{kg}$ of $\mathrm{C}$ or $\mathrm{N}$ applied in lake weed refuse.

${ }^{y}$ Carbon pools for each lake weed rate are significantly different at $P<0.05$.

${ }^{\mathrm{x}}$ There was no significant difference between the rate treatments for $\mathrm{N}$ parameters.

Table 3. Capillary and total porosity of soil amended with lake weed.

\begin{tabular}{lcc}
\hline $\begin{array}{c}\text { Application rate } \\
\left(\mathrm{Mg} \cdot \mathrm{ha}^{-1} \text { dry wt }\right)\end{array}$ & $\begin{array}{c}\text { Total porosity } \\
\left(\mathrm{m}^{3} \cdot \mathrm{m}^{-3}\right)\end{array}$ & $\begin{array}{c}\text { Capillary porosity } \\
\left(\mathrm{m}^{3} \cdot \mathrm{m}^{-3}\right)\end{array}$ \\
\hline $\begin{array}{c}\text { Lake weed } \\
\text { Control }(0)\end{array}$ & $48.2 \mathrm{a}$ & $15.7 \mathrm{c}^{\mathrm{z}}$ \\
206 & $50.6 \mathrm{a}$ & $18.4 \mathrm{a}$ \\
161 & $50.7 \mathrm{a}$ & $18.3 \mathrm{a}$ \\
96 & $49.9 \mathrm{a}$ & $16.9 \mathrm{~b}$ \\
\hline
\end{tabular}

${ }^{\mathrm{z}}$ Values in a column followed by the same letter are not significantly different $(P=0.05)$.

of trace elements.

Aerobic incubation. A 47 dincubation study was conducted to determine the mean residence time and amount of readily available $\mathrm{C}$ and $\mathrm{N}$ fractions in lake weed biomass. Cumulative $\mathrm{N}$ data provided an estimate of the amount of PAN supplied by lake weed waste. Carbon decomposition data has been used to estimate net $\mathrm{N}$ mineralization of applied materials in the first $30 \mathrm{~d}$ after application (Gilmour et al., 1985). A sum of squares reduction test indicated that the rapidly available $\mathrm{C}$ pool was significantly different for each application rate. The readily available C pool was 540, 599, and $647 \mu \mathrm{g} \cdot \mathrm{mg}^{-1}$ for the 96,161 , and $206 \mathrm{Mg} \cdot \mathrm{ha}^{-1}$ treatments, respectively (Table 2). The mean residence times (MRT), calculated by taking the reciprocal of the decay rate, were $8 \mathrm{~d}$ for the 96 and $161 \mathrm{Mg} \cdot \mathrm{ha}^{-1}$ rates and 10 for the $206 \mathrm{Mg} \cdot \mathrm{ha}^{-1}$ rate. The amount of $\mathrm{N}$ in the pool of potentially mineralizable $\mathrm{N}$ and its decay rate were not statistically significant between the three treatments. The pool of potentially mineralizable $\mathrm{N}$ was estimated to be $225 \mathrm{~g} \cdot \mathrm{kg}^{-1}$ and had a MRT of $16 \mathrm{~d}$ (Table 2). Stanford et al. (1973) found that the mean residence time of $\mathrm{C}$ and $\mathrm{N}$ substrates under field conditions is between 1 and 3 times that of a laboratory incubation at $25^{\circ} \mathrm{C}$.

Carbon evolved was greatest on the treatment with the lowest rate (Table 2). Lower C turnover rates were likely due to environmental changes during the incubation caused by the addition of excess substrate $\mathrm{C}$ and N. High substrate concentrations select for microbial populations with low yield coefficients and high growth rates (Shen and Bartha, 1996a). Within anaerobic microsites, $\mathrm{C}$ respiration may have dropped such that the potential for $\mathrm{NH}_{3}$ volatilization and/or denitrification was augmented.

The percent substrate decomposed and decay constants were well correlated with $\mathrm{C}$ and $\mathrm{N}$ mineralization values obtained from incubations with alfalfa. Gilmour et al. (1985) reported that alfalfa had an $\mathrm{N}$ content of 41 $\mathrm{g} \cdot \mathrm{kg}^{-1}$ and a $\mathrm{C}: \mathrm{N}$ ratio of 9 similar to lake weeds $(C: N=10)$. The decay constants reported for the rapid fraction of alfalfa under aerobic conditions were 8.5 and $8 \mathrm{~d}$ (Gale and Gilmour, 1988; Gilmour et al., 1985). The alfalfa substrate constituting the very rapid and rapid fractions as defined by Gilmour et al. (1985) appeared to decompose within the first $10 \mathrm{~d}$. Together these fractions made up $45 \%$ of the total substrate $\mathrm{C}$. The amount of substrate $\mathrm{C}$ evolved from lake weeds by day 10 were $40 \%$, $44.6 \%$, and $40.3 \%$ from low to high application rates, respectively. The $\mathrm{C}$ decay rates for the $47 \mathrm{~d}$ incubation, i.e., 10 to $8 \mathrm{~d}$ are consistent with these results (Table 2). Under aerobic conditions $57 \%$ of the alfalfa substrate $\mathrm{C}$ had decomposed by the end of a $30 \mathrm{~d}$ incubation (Gale and Gilmour, 1988). On day 30 of the lake weed incubation $60 \%, 57.5 \%$, and $51 \%$ of substrate $\mathrm{C}$ had decomposed on the 206,161 , and $96 \mathrm{Mg} \cdot \mathrm{ha}^{-1}$ treatment, respectively. While
$55 \%$ to $62 \%$ of the substrate $\mathrm{C}$ was evolved as $\mathrm{CO}_{2}$, only $22.5 \%$ of the substrate $\mathrm{N}$ mineralized was in the form of $\mathrm{KCl}$ extractable $\left(\mathrm{NH}_{4}\right.$ $+\mathrm{NO}_{3}$ )- $\mathrm{N}$ at day 47 (Table 2).

Certain factors in a soil system can mimic a priming effect. A soil exhibits a priming effect if new organic inputs stimulate or retard decomposition of organic matter present in the soil (Jansson and Persson, 1982; Jenkinson, 1966). The most common cause of an alleged priming effect is the turnover of $\mathrm{C}$ in microbial biomass (Wu et al., 1993). After sequential growth of a microbial population occurs in the presence of high substrate concentration, there may be a flush of $\mathrm{N}$ mineralization (Voroney and Paul, 1984). Therefore, much of the $\mathrm{N}$ mineralized may have come from the initial microbial population rather than the lake weed substrate. Without conducting a tracer experiment, the source of $\mathrm{C}$ and $\mathrm{N}$ and the existence of a priming effect could not be corroborated. Net $\mathrm{CO}_{2}$ evolution must exceed $100 \%$ of the substrate Cadded within a period of 2 to 5 weeks to substantiate a priming effect in the absence of tracers (Shen and Bartha, 1996b). The priming effect is brief lasting at most several months but can measurably effect the decomposition of soil organic matter (SOM). In 2 months, SOM in soil cropped to soybean (Glycine max) and sunflower (Helianthus annuus) decomposed $69.9 \%$ and $38.5 \%$ faster than soils planted to sorghum (Sorghum bicolor) and amaranthus (Amaranthus hypochondriacus). Based on these and similar studies, it is feasible that the quantity of SOM could fluctuate after several seasons of experiencing a priming effect.

Assessment of turfgrass sod establishment, growth, and quality. Lake weed amended soil had significantly higher capillary porosity and higher plant-available soil water, while total porosity was not affected by amendments (Table 3). Increased soil moisture and nutrient levels in lake weed amended plots led to accelerated germination and rate of establishment. However by mid-June, all amended plots had over $80 \%$ cover (Table 4 ). Nitrogen and soil moisture were lower on control treatments which was consistent with lower ratings for percent cover and turfgrass growth on all dates (Tables 4 and 5). Increases in turfgrass cover and quality were due in part to the plantavailable N (PAN) mineralized from the lake weed biomass.

In addition to better establishment rates, lake weed amendments resulted in fewer broadleaf weeds in control plots on 20 June and less crabgrass encroachment on 2 Sept. (Table 4). Herbicides were not applied before assessment of broadleaf weeds and crabgrass encroachment. This reduction in weeds in lake weed amended plots occurred because of increased water-holding capacity and additional $\mathrm{N}$ that resulted in more rapid establishment and higher turfgrass density. Amending the soil with lake weeds resulted in significantly greater growth and $\mathrm{N}$ content of grass relative to the untreated control (Tables 5 and 6). Lake weed amendments showed improved turfgrass quality relative to the control throughout the 1996 season (Table 7), significantly enhancing sod establishment and turf density with 
Table 4. Effect of lake weed soil amendment on turfgrass sod in 1996.

\begin{tabular}{|c|c|c|c|}
\hline 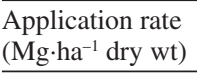 & $\begin{array}{l}\text { Percent cover }(\%) \\
20 \text { June }\end{array}$ & $\begin{array}{l}\text { Broadleaf weeds } \\
\text { 20 June }\end{array}$ & $\begin{array}{c}\text { Crabgrass }^{z} \\
2 \text { Sept. }\end{array}$ \\
\hline \multicolumn{4}{|l|}{ Lake weed } \\
\hline Control (0) & $64 c^{y}$ & $5.5 \mathrm{a}$ & $7.2 \mathrm{a}$ \\
\hline 206 & $88 \mathrm{a}$ & $1.4 \mathrm{c}$ & $1.0 \mathrm{~b}$ \\
\hline 161 & $83 \mathrm{~b}$ & $2.2 \mathrm{~b}$ & $1.4 \mathrm{~b}$ \\
\hline 96 & $81 \mathrm{~b}$ & $2.5 \mathrm{~b}$ & $2.0 \mathrm{~b}$ \\
\hline
\end{tabular}

yPlot ratings were done visually using a scale from 1 to 9 ( $1=$ absence of weeds, $9=$ entirely weeds $)$.

${ }^{z}$ Values in a column followed by the same letter are not significantly different $(P=0.05)$.

Table 5. Effect of lake weed soil amendment on turfgrass clipping weights in 1996.

\begin{tabular}{llllll}
\hline $\begin{array}{l}\text { Application rate } \\
\left(\mathrm{Mg} \cdot \mathrm{ha}^{-1} \text { dry wt) }\right.\end{array}$ & \multicolumn{5}{c}{ Dry clipping weights per plot $\left(\mathrm{g} \cdot \mathrm{m}^{-2}\right)^{\mathrm{z}}$} \\
\cline { 2 - 6 } & 3 July & 19 July & 6 Aug. & 21 Sept. & 26 Oct. \\
\hline Lake weed & & & & \\
Control (0) & $8.88 \mathrm{a}$ & $2.04 \mathrm{a}$ & $1.30 \mathrm{a}$ & $2.04 \mathrm{a}$ & $0.89 \mathrm{a}$ \\
206 & $7.56 \mathrm{c}$ & $6.00 \mathrm{~b}$ & $5.22 \mathrm{~b}$ & $5.52 \mathrm{~b}$ & $3.22 \mathrm{c}$ \\
161 & $4.07 \mathrm{~b}$ & $6.33 \mathrm{~b}$ & $4.15 \mathrm{~b}$ & $5.44 \mathrm{~b}$ & $2.59 \mathrm{~b}$ \\
96 & $4.85 \mathrm{~b}$ & $4.85 \mathrm{~b}$ & $4.33 \mathrm{~b}$ & $2.30 \mathrm{~b}$ \\
\hline
\end{tabular}

${ }^{2}$ Values in column followed by the same letter are not significantly different $(P=0.05)$.

Table 6. Effect of lake weed soil amendment on N content of clippings in 1996.

\begin{tabular}{|c|c|c|c|c|c|}
\hline \multirow{2}{*}{$\begin{array}{l}\text { Application rate } \\
\left(\mathrm{Mg} \cdot \mathrm{ha}^{-1} \text { dry wt) }\right.\end{array}$} & \multicolumn{5}{|c|}{$\mathrm{N}$ content in clippings $\left(\mathrm{g} \cdot \mathrm{kg}^{-1}\right)^{\mathrm{z}}$} \\
\hline & 3 July & 19 July & 6 Aug. & 21 Sept. & 6 Oct. \\
\hline \multicolumn{6}{|l|}{ Lake weed } \\
\hline Control (0) & $27 \mathrm{~b}$ & $43^{\mathrm{NS}}$ & $37 \mathrm{c}$ & $30 \mathrm{~b}$ & $28 \mathrm{c}$ \\
\hline 206 & $37 \mathrm{a}$ & $42^{\mathrm{NS}}$ & $42 \mathrm{~b}$ & $38 \mathrm{a}$ & $37 \mathrm{~b}$ \\
\hline 161 & $37 \mathrm{a}$ & $41^{\mathrm{NS}}$ & $45 \mathrm{a}$ & $40 \mathrm{a}$ & $39 a$ \\
\hline 96 & $35 \mathrm{a}$ & $43^{\mathrm{NS}}$ & $46 \mathrm{a}$ & $40 \mathrm{a}$ & $43 \mathrm{a}$ \\
\hline
\end{tabular}

${ }^{\mathrm{z}}$ Values in a column followed by the same letter are not significantly different $(P=0.05)$.

yNonsignificant.

Table 7. Effect of lake weed amendment on turfgrass quality in 1996.

\begin{tabular}{lllll}
\hline $\begin{array}{l}\text { Application rate } \\
\left(\mathrm{Mg} \cdot \mathrm{ha}^{-1} \text { dry wt) }\right.\end{array}$ & \multicolumn{4}{c}{ Turfgrass quality rating } \\
\cline { 2 - 4 } & 20 June & 3 July & 21 Sept. & 16 Nov. \\
\hline Lake weed & $2.2 \mathrm{~d}^{\mathrm{z}}$ & $2.5 \mathrm{c}$ & $3.7 \mathrm{~b}$ & $4.5 \mathrm{c}$ \\
Control (0) & $8.4 \mathrm{a}$ & $8.4 \mathrm{a}$ & $7.7 \mathrm{a}$ & $7.2 \mathrm{a}$ \\
206 & $7.7 \mathrm{~b}$ & $7.9 \mathrm{ab}$ & $7.5 \mathrm{a}$ & $7.0 \mathrm{ab}$ \\
161 & $6.1 \mathrm{c}$ & $7.0 \mathrm{~b}$ & $7.5 \mathrm{a}$ & $6.5 \mathrm{~b}$ \\
96 &
\end{tabular}

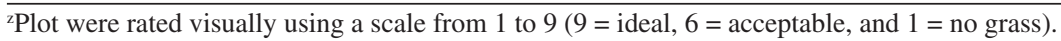

${ }^{y}$ Values in a column followed by the same letter are not significantly different $(P=0.05)$.

decreased weed pressure. It is not likely that turfgrass quality increased solely due to PAN in lake weed refuse. Therefore, management concerns during the application of lake weeds should focus on nutrient loading and the timing of PAN release. Plant-available $\mathrm{N}$ was in excess of turfgrass $\mathrm{N}$ requirements on all lake weed treatments $\left(570,960\right.$, and $\left.1200 \mathrm{~kg} \cdot \mathrm{ha}^{-1}\right)$. Excess $\mathrm{N}$ at the higher lake weed application rates could decrease root growth due to excess topgrowth, resulting in weaker sod (Beard, 1973) and lead to $\mathrm{NO}_{3}-\mathrm{N}$ leaching. Therefore, part of the increase in turfgrass quality may have been due to increases in plant-available $\mathrm{H}_{2} \mathrm{O}$.

\section{Summary}

The lake weed material contained essential plant nutrients and was low in trace elements. A megagram (dry weight) of lake weeds contained $0.37 \mathrm{~kg}$ of $\mathrm{P}$ and $2.5 \mathrm{~kg}$ of $\mathrm{K}$. At the rates applied to the incubation study, 570, 960, and $1200 \mathrm{~kg}$ PAN/ha would be available for crop growth in a single growing season. These rates are well above $\mathrm{N}$ fertilizer recommendations for turfgrass sod and field crops. In Michigan, average turfgrass $\mathrm{N}$ fertilizer rates are normally between 200 and $300 \mathrm{~kg} \cdot \mathrm{ha}^{-1}$ and the $\mathrm{N}$ fertilizer recommendation for field corn with a yield goal of $74 \mathrm{Mg} \cdot \mathrm{ha}^{-1}$ is $\mathrm{N}$ at $280 \mathrm{~kg} \cdot \mathrm{ha}^{-1}$ (Beard, 1973; Christenson et al., 1992; Rieke and Lyman, 1999).

While lake weed applications significantly enhanced sod establishment and turfgrass quality resulting in decreased weed pressure, excess PAN at higher lake weed application rates could result in $\mathrm{NO}_{3}-\mathrm{N}$ leaching and diminished root growth causing a weaker sod. Therefore, management concerns during the application of lake weeds should focus on nutrient loading and the timing of PAN release. Land application of lake weed refuse could ease waste disposal problems, reduce fertilizer inputs for sod growers and improve the moisture status of sands. Depending on methods of weed harvesting, we observed that large amounts of unwanted trash present in the plant biomass could discourage use by growers. Debris was removed manually with rakes before application of the lake weed refuse.

Although the project was limited to a growing season and one township, our characterization of lake weed refuse would be useful to individuals land applying material that contained a similar mix of lake weed species. Our results indicate that lake weed application rates should be based on the $\mathrm{N}$ requirement of the crop to be grown. Given the nutrient analyses and release rate information, land application of lake weed refuse can be used to reduce fertilizer inputs for sod growers and can improve the moisture status of sands. Further, this information can be of value to environmental regulatory agencies in determining safe and proper use of such waste materials.

\section{Literature Cited}

American Society for Testing and Materials. 1997. Standard test method for saturated hydraulic conductivity, water retention, porosity, particle density, and bulk density of putting green and sports turf rootzones. Natural Playing Surfaces Subcommittee, ASTM Sports Equipment and Facilities F-8. ASTM F1815-97. ASTM West Conshohocken, $\mathrm{Pa}$.

Blake, G.R. and K.H. Hartge. 1986. Bulk density, p. 363-375. In: A. Klute (ed.). Methods of soil analysis. Part 1. 2nd ed. ASA-SSSA Agron. Monogr. 9.

Beard, J.B. 1973. Turfgrass: Science and culture. Prentice-Hall, Englewood Cliffs, N.J.

Bremner, J.M. and C.S. Mulvaney. 1982. Salicylic acid-thiosulfate modification of Kjeldahl method to include nitrate and nitrite, p. 621. In: A.L. Page et al. (eds.). Methods of soil analysis. Part 2. 2nd ed. ASA-SSSA Agron. Monogr. 9.

Christenson, D.R., D.D. Warncke, M.L. Vitosh, L.W. Jacobs, and J.G. Dahl. 1992. Fertilizer recommendations for field crops in Michigan. Mich. State Univ. Coop. Ext. Serv. Bul. E-550A.

Danielson, R.E. and P.L. Sutherland. 1986. Porosity, p. 443-460. In A. Klute (ed.). Methods of soil analysis. Part 1. 2nd ed. ASA-SSSA Agron. Monogr. 9.

Dou, Z., D.D. Galligan, R.D. Allshouse, J.D. Toth, C.F. Ramburg, Jr., and J.D. Ferguson. 2001. Manure sampling for nutrient analysis: Variability and sampling efficacy. J. Environ. Qual. 30(4): 1432-1437.

Gale, P.M. and J.T. Gilmour. 1988. Net mineralization of carbon and nitrogen under aerobic and anaerobic conditions. Soil Sci. Soc. Amer. J. 52:1006-1010.

Gilmour, J.T., M.D. Clark, and G.C. Sigua. 1985. Estimating net nitrogen mineralization from carbon dioxide evolution. Soil Sci. Soc. Amer. J. 49:1398-1402.

Griffiths, R.W. 1993. Effects of zebra mussels (Dreissena polymorpha) on the benthic fauna of Lake St. Claire, p. 415-437. In: T.F. Nalepa and D.W. Schloesser (eds.). Zebra mussels: Biology, impacts, and control. Lewis Publ.-CRC Press, Boca Raton, Fla.

Hartz, T.K., F.J. Costa, and W.L. Schrader. 1996. Suitability of composted green waste for horticultural uses. HortScience 31(6):961-964.

Heckman, J.R. and D. Kluchinski. 1996. Chemical composition of municipal leaf waste and handcollected urban leaf litter. J. Environ. Qual. 25:355-362.

Jansson, S.L. and J. Persson. 1982. Mineralization and immobolization of soil nitrogen. In: F.J. Stevenson (ed.). Nitrogen in agriculture soils. Agronomy 22:229-252.

Jenkinson, D.S. 1966. The priming action, p. 
199-208. In: The use of isotopes in soil organic matter studies. FAO-IAEA, Pergamon Press, New York.

Landschoot, P.J. and A.S. McNitt. 1994. Selecting composts to improve your turf. Turfgrass Trends 4:1-5.

Loschinkohl, C. and M.J. Boehm. 2001. Composted biosolids incorporation improves turfgrass establishment on disturbed urban soil and reduces leaf rust severity. HortScience 36(4):790-794.

Nalepa, T.F., D.J. Hartson, G.W. Gostenik, D.L. Fanslow, and G.A. Lang. 1996. Changes in the freshwater mussel community of Lake St. Clair: From unionidae to Dreissena polymorpha in eight years. J. Great Lakes Res. 22(2):354-396.

Norrie, J. and A. Gosselin. 1996. Paper sludge amendments for turfgrass. HortScience 31(6):957-960.

Paul, E.A., J.S. Morris, and S. Böhm., 2001. The determination of soil $\mathrm{C}$ pool sizes and turnover rates: Biophysical fractionation and tracers, $\mathrm{p}$ 193-206. In: R. Lal, J.M. Kimble, and R.F. Follett (eds.). Assessment methods for soil C pools. CRC Press, Boca Raton, Fla

Rieke, P.E. and G.T. Lyman. 1999. Fertilizing home lawns to preserve water quality. Mich. State Univ. Ext. Bul. TURF-0103. www.turf.msu.edu.

Rodriguez, I.R. and G.L. Miller. 2000. Using near infrared reflectance spectroscopy to schedule nitrogen applications on dwarf-type bermudagrasses. Agron. J. 92:423-427.

SAS Institute, Inc. 1988. SAS procedures guide, release 6.03 ed. SAS Inst., Inc., Cary, N.C.

Shen, J. and R. Bartha. 1996a. Metabolic efficiency and turnover of soil microbial communities in biodegradation tests. Appl. Environ. Microbial 62(7):2411-2415.

Shen, J. and R. Bartha. 1996b. Priming effect of sub- strate addition in soil-based biodegradation tests. Appl. Environ. Microbial. 62(4):1428-1430.

Stanford, G., M.H. Frere, and D.H. Schwaninger. 1973. Temperature coefficient of soil nitrogen mineralization. Soil Sci. 115:321-323.

Talpaz, H., P. Fine, and B. Bar-Yosef. 1981. An the estimation of $\mathrm{N}$-mineralization parameters from incubation experiments. Soil Sci. Soc. Amer. J. 45:993-996.

Voroney, R.P. and E.A. Paul. 1984. Determination of $\mathrm{k}_{\mathrm{c}}$ and $\mathrm{k}_{\mathrm{n}}$ in situ for calibration of the chloroform fumigation-incubation method. Soil Biol. Biochem. 16(1):9-14.

Wu, J., P.C. Brookes, and D.S. Jenkinson. 1993. Formation and destruction of microbial biomass during the decomposition of glucose and ryegrass in soil. Soil Biol. Biochem. 25(10):1435-1441. 